\title{
How to Study People Who Do Not Want to be Studied Practical Reflections on Studying Up
}

Souleles, Daniel

Document Version

Accepted author manuscript

Published in:

PoLAR: Political and Legal Anthropology Review

DOI:

10.1111/plar.12253

Publication date:

2018

License

Unspecified

Citation for published version (APA):

Souleles, D. (2018). How to Study People Who Do Not Want to be Studied: Practical Reflections on Studying Up. PoLAR: Political and Legal Anthropology Review, 41(S1), 51-68. https://doi.org/10.1111/plar.12253

Link to publication in CBS Research Portal

\section{General rights}

Copyright and moral rights for the publications made accessible in the public portal are retained by the authors and/or other copyright owners and it is a condition of accessing publications that users recognise and abide by the legal requirements associated with these rights.

Take down policy

If you believe that this document breaches copyright please contact us (research.lib@cbs.dk) providing details, and we will remove access to the work immediately and investigate your claim. 


\section{How to Study People Who Do Not Want to be Studied: Practical Reflections on Studying Up Daniel Souleles}

Journal article (Accepted manuscript*)

\section{Please cite this article as:}

Souleles, D. (2018). How to Study People Who Do Not Want to be Studied: Practical Reflections on Studying Up. PoLAR: Political and Legal Anthropology Review, 41(S1), 51-68. 00I: 10.1111/plar.12253

This is the peer reviewed version of the article, which has been published in final form at DOI:

$$
\text { https://doi.org/10.1111/plar.12253 }
$$

This article may be used for non-commercial purposes in accordance with Wiley Terms and Conditions for Self-Archiving

* This version of the article has been accepted for publication and undergone full peer review but has not been through the copyediting, typesetting, pagination and proofreading process, which may lead to differences between this version and the publisher's final version AKA Version of Record.

Uploaded to CBS Research Portal: July २०19 


\section{Daniel Souleles}

Copenhagen Business School

\section{How to Study People Who Do Not Want to be Studied: Practical Reflections on Studying Up}

In attempts to gain a wider understanding of the social worlds they encounter, anthropologists have exhorted their colleagues to "study up" and pay attention to wealthy and powerful people, not just those at society's margins. Anthropology has met this call. However, anthropologists could stand to be more forthcoming in explaining readily generalizable research strategies for studying people who are difficult to access. This article offers a brief methodological introduction to the literature on studying up and the anthropology of finance, and then shares a sampling of failures and successes from my own two-year research, using private equity investors as one case of accessing an elite network. I suggest anthropologists are best served in finding multiple public sites and building informant networks with people from these sites. [studying up, finance, private equity, ethnography, methods, failure]

Anthropology is a profession in which adventure plays no part; merely one of its bondages, it represents no more than a dead weight of weeks or months wasted en route; hours spent in idleness when one's informant has given one the slip; hunger, exhaustion, illness as like as not; and those 
thousand and one routine duties which eat up most of our days to no purpose. ... It may be that we shall have spent six months of travel privation, sickening physical weariness in order to record - in a few days, it may be, or even a few hours - an unpublished myth, a new marriagerule, or a complete list of names of clans. (Lévi-Strauss 1968, 17)

\section{The Call}

Over the last forty years or so, there have been calls within the discipline of anthropology to leave behind exclusive focus on people at the peripheries of capitalism or imperial systems, people who have made up the majority of anthropological studies, in favor of "studying up" those elusive few with power and wealth. The idea of studying up, in tandem with "studying down," is to create an ethnographic record that takes full account of a wider social circuit (Gusterson 1996, 1997; Nader 1972). Gusterson, in particular, has gone so far as to suggest that, given this wider research commitment, anthropologists may have to reconsider their blind commitment to participant observation (horror of horrors) and imagine new ways to engage with their informants.

These calls to study up have echoed in other disciplines as well, from sociology (Sherwood 2010, 14-15), to political science (e.g., Page, Bartels, and Seawright 2013; Winters 2011), to economics (Stiglitz 2011, 2013), and to history (Levy 2012; Ott 2011). ${ }^{1}$ These trends toward the study of elites, too, have led to a minor literature on the mechanics of studying up and interviewing elites, advising on everything from comportment (Mikecz 2012; Stephens 2007), to dress (Conti and O’Neil 2007, 73), and 
even to maintaining confidence and composure in the face of assertive informants in interviews (Harvey 2011); in brief, how to prepare for your interviews. This studying up is hard to do, particularly if people have the opportunity to decline the polite offers of anthropological study or have lives that are structured so as to render them inaccessible, or even evanescent. After all, as in my case study, a private equity executive may have some say in the clothes I wear (say, J. Crew), the food I eat (e.g., Heinz, Smithfield), or even the computer I use (e.g., Dell); these are all companies that were controlled by private equity $(\mathrm{PE})$ at one point or another. Meanwhile, PE executives are not necessarily present at these companies or alongside their products.

All the tactics literature in the world cannot help if you cannot find the people you want to interview or if your sample becomes too narrow. What, then, is one to do?

From June 2012 to September 2014, I conducted a study seeking to answer why PE investors buy, manage, and sell their companies. I was interested in finding out how such a relatively small group of people (perhaps 10,000 in the entire world) have such an outsized effect on the businesses that make up much of our world and who control the wealth those businesses generate. Put another way, I was interested in the processes and logics by which private equity investors exercised their power and the effects of that power on people's everyday lives. Private equity firms and their managers use other people's money, and even more borrowed money, to buy control of whole companies and then manage them as investments. After a period of three to ten years of hiring and firing different managers, implementing reorganization plans, and paying down loans, PE investors seek to sell their investment companies for a profit. Typically, they collect 2 
percent of the total amount of money they managed plus 20 percent of any profits generated (often after some "hurdle" or bare-minimum rate of return).

As my study came to an end, the 2014 Prequin Global Private Equity Report noted that, as of 2013 , the private equity industry managed $\$ 3.5$ trillion dollars of mostly other people's money, and made 2,836 buyout deals in that year (Fogarty 2014, 4). This likely represented about 10 percent of all global company-buying. ${ }^{2}$ Private equity investors are "supermanagers," that is, they are highly paid people who are able to flit among industries and productive strategies to manage all manner of different businesses (Appelbaum and Batt 2014; Ho 2015).

This is about as "up" as one can study; and I suggest that my travails offer a good case study not only in methods of access but also the ways in which elites can control the flow of people who are allowed to enter into their social space. If someone wants to study elites, some sense of how this process works is needed, even if a researcher is not ultimately interested in the operation of social power. In order to study the processes and logics of private equity investing over two years of fieldwork, I conducted life history and ethnographic work interviews with eighty-three financial people, accumulated 103 interviews, attended sixteen industry conferences and events, as well as "hung out" in offices and at business schools when I was welcome to do so.

Reporting my results in this type of aggregate, while a fairly formulaic accounting of research activity, is misleading. In my first year of research, I simply did not know how to find the PE managers I needed to talk to or what would be a reasonable expectation of research collaboration if I did find them. There was no place to go, and the 
advertised, preferred way of getting in touch, according to company websites, was through secretaries and over e-mail, all of which seemed more methods of shutting down inquiries than starting conversations.

I knew that the project was worthwhile, with larger disciplinary questions on finance and studying up; after all, to my knowledge, no one outside myself had done an in-depth study of private equity investors and how their investment decisions make select people and institutions wealthy as well as structure other people's lives (Souleles 2017a). At this point in my research, however, I felt that the project would be a failure. In my second year of research, by contrast, I found methods that allowed me to conduct the bulk of the interviews and observations that made up my data, requiring me to ignore some of the norms, or at least advertised preferences, of how to initiate contact with informants. Ultimately, I was able to create a model of private equity's interpretive schemas, compare this to other financiers, and then cross-culturally and cross-historically compare the inequality financiers create to that observed by other anthropologists and archaeologists in other times and places (e.g., Flannery and Marcus 2012). ${ }^{3}$

While I dwell on the substance of my findings elsewhere (Souleles 2017a, 2017b, forthcoming), in what follows I inventory the informant-gathering strategies offered by my colleagues in other ethnographic accounts of finances. I suggest that much of the literature, while successful in its own way, offers methods and strategies that are not readily generalizable and often includes samples of small groups or one or two institutions that can make findings a bit too narrow for comparison to the larger world of finance. I explain one of my failed strategies to gather informants, and suggest that it 
didn't work because I tried to use fieldwork strategies that were inappropriate to studying hard-to-access people with whom I had no personal connection. I also explain two strategies that allowed me to find informants and sites of observation: attending industry conferences and following professionals on social media.

The common thread running through both strategies was recognition that my project would take me to multiple ethnographic sites (Marcus 1995), and that I would have to seek out PE managers in public places (cf. Tett 2010). These strategies are much like ones that Ortner (2010) used to find informants and observation sites in her study of Hollywood; and, incidentally, much like the ones people seeking jobs in finance might take. Ortner used a technique she called "interface ethnography," that is, identifying events and sites at which a population that is hard to access presents itself to the public. Not only do these "interface events" open up closed worlds but also they tend to offer a cross-section of the social world that is a bit broader than simple chain referral or snowball sampling might provide (Atkinson and Flint 2001; Biernacki and Waldorf 1981, $143 n)$.

In Ortner's case, she found strivers, up-and-comers, as well as established industry professionals at the entertainment conferences she attended. In my case, at finance conferences, I found both private equity investors as well as an army of associated and affiliated professionals who make their work through investment activities. After I learned these lessons, I was able to transcend my own training and sense of anthropology, which had focused on an older, romantic strain in the discipline that sees a fieldworker wedded to a lonely site and an out-of-the-way community-- what I 
have come to think of as the "Malinowski Reenactment Society" (cf. Malinowski [1922] 1965) -and was actually able to answer my research questions, despite having no fixed site and no stable group.

In my understanding of my training, classic ethnographic methods had been put on a pedestal at the expense of following concrete research questions. Working through this project had me correct my thinking to use an eclectic set of methods at the service of my guiding questions on private equity effects and PE managers' social roles. Based on my experience, I suggest two course corrections for the study of the powerful: (1) discard unhelpful advice from other examples of studying up, and (2) scrutinize the idea that of what an ethnographic site is . In fact, ethnographic sites should be thought of as all the places touched by a given social process, with focus, and perhaps priority, given to the

part of the process that answers a given research question. In my case, for example: Who is hurt or helped by the private equity deal process? Focusing on a research question led me to a cluster of sites, which initiated and facilitated access to other sites.

\section{The Anthropology of Finance}

The anthropology of finance is a growing subfield of cultural anthropology. Anthropologists have studied, for example, Japanese arbitrage traders (Miyazaki 2013), the Chicago Board of Trade (Zaloom 2006), American investment bankers (Ho 2009), international currency derivatives (LiPuma and Lee 2004), central bankers (Holmes 2014), Islamic mortgages (Mauer 2006), and the legal infrastructure of international financial markets (Riles 2011). Anthropologists are also starting to pick up on how to 
include the actions of financiers in their descriptions of other people's lives (e.g., Weiss 2015). However, given this wonderful breadth, little generalizable advice is offered for how to conduct such a study and gather informants.

As noted above, as in any ethnographic study, a large part of studying up is negotiating access and building rapport, doubly so if you conceive of the endeavor as gaining partial entre into a given elite network. Understanding the dynamics of networks of finance professionals, how people enter them, and how to gain rapport is every bit as useful as the knowledge of the cultures that those networks structure and bound (cf. Nader 1972, 18). Moreover, anthropologists have problems with access of studying up or down. Sometimes, people do not want to talk to you. At other times, an entire elite network is welcoming. Shamus Kahn (2010) was able to return to his boarding high school as a faculty member to conduct his study, Privilege: The Making of an Adolescent Elite at St. Paul's School. The school even allowed Kahn to use its real name. Kahn's case also illuminates the point that not all elites structure access in the same way-a boarding school works differently than a private equity firm. Moreover, it also shows the ways in which the subject position of the researcher can ease access - in Kahn's case, as a successful alumnus, he had backdoor entrance.

Caitlin Zaloom $(2006,8)$, studying the world of finance in publicly traded markets, was able to start her research by getting a job as a runner at the Chicago Board of Trade through a family friend. Similarly, a close friend of Hirokazu Miyazaki's mother "introduced [Miyazaki] to the manager of a derivatives unit inside a securities firm where 
[he] later conducted field research. Without this introduction, the project would never have taken off" (Miyazaki 2013, xi).

An occasional strategy is to get a job in the organization one is studying. Ho (2009) found work in an investment bank, though not as an investment banker, in order to gain general background knowledge: "As a financial services consultant within an investment bank, [Ho] was trained and immersed in the perspectives and mores of Wall Street financial practices" (14). Ho was later able to use the network of people she met at her job as well as alumni connections from Princeton University to make an informant network to talk to people about investment banking. Sometimes, an anthropologist is able to find a magic informant that seems to open a whole world. Fisher (2012), in her study, notes:

My actual "entry" could not, however, have transpired without the enormous interest, help, and insight of a then middle-aged woman returning to school for a masters in liberal arts at Columbia University with a focus on anthropology. I met Madeline Winters in one of my courses on American culture. She came from the higher tiers of New York and American "society"-what some might call "old money."... Madeline, her investment-banking friend Mindy Plane, and I sat down for a 7:00 AM breakfast at Le Brasserie on East 53rd Street. They collaboratively came up with a list of about twenty first-generation Wall Street women whom I could contact at their recommendation. An 
astonishing number of the women - nearly all of them-agreed to participate in my study. (20-21)

I read these accounts with a bit of envy; I encountered no such magical informant or golden connection. It is also worth noting that all the above ethnographers likely or explicitly made use of research methods beyond finding a special informant, although this often falls by the wayside for reasons of narrative exigency. Ethnographers often talk of these magic moments as a literary trope to vouch for ethnographic authority, moments in which a world opens up, a gate comes down, and free-range social facts come dancing into view. Make no mistake, I personally am no martyr and would have leapt at each of the above opportunities; yet, they did not happen. Even in the event that friends and colleagues referred me to people, the informants were often tangential to private equity (though immersed in finance of one sort or another), and often did not open any significant networks.

I began to feel sympathy for Gusterson (1996) in his lament on attempting to study nuclear weapons scientists: "When [Gusterson] arrived in Livermore [he] had to figure out how to study, first, a laboratory with 8,000 employees whom [he] was forbidden by national security laws from observing at work" (32). I, at the start of the PE project, lived in New York City, could see the towers of Midtown, but had no one to let me in. While acknowledging that an openness to serendipity in ethnographic research is a virtue (Merton and Barber 2006), I suggest that exclusively relying on providence and 
lucky breaks, as the literature on studying up presents as examples, is likely to lead more to heartache than a research site or data. My own case provides one such example.

\section{Failure}

Long-term, unstructured, participant observation is what my training would have had me do, and in fact is what I set out to do. Geertz (1973) suggested that, more than any theoretical commitment, it was long-term, open-ended fieldwork-ethnography - that distinguished anthropology from other social sciences (5-6). Cohen (2000) gives some sense of the place participant observation fieldwork has in the discipline:

Participant observation is one of the cornerstones of anthropological research. Used with intensive interviews and central to long-term fieldwork, participant observation helps us experience daily life firsthand, clears a path to understanding, and acts as a point of reference for local practices that might otherwise remain obscure or strange to the passive observer. In its mythic structure, participant observation is the rite of passage that all anthropology students endure. It is described as the most important act, the "being there" that leads inexorably to ethnographic understanding. (316-17, internal cites removed)

In sum, there is a feeling in some corners of anthropology, and among ethnographic classics, that unless a researcher does open-ended participant observation fieldwork, it is 
not ethnography. If not doing ethnography, a researcher cannot describe culture; and if one cannot describe culture, one might as well go home. Mercifully, this is ringing as increasingly outdated, particularly as the study of social processes that transcend individual groups and geographic locations becomes more important to anthropologists. This ethos, too, is reflected in the brief overview of the anthropology of finance noted above. The researchers tended to write about personal, one-off connections that led to a particular network or social world. The researchers, via chain referral or key informant sampling, conjure a bounded group that often resides in a specific place (the Chicago Board of Trade or Midtown Manhattan, say) through these social networks, and then make this the object of their study. At the start of my project, I, too, was trying to fashion a group and do participant observation.

With these goals in mind, I called and/or e-mailed one hundred PE firms, drawn from a sample of 353 firms that sponsor the New York Private Equity Network, a network for young private equity professionals in New York City. They all declined. Some said that they were just winding down a fund and that it would not be an interesting time to observe things. Others claimed policy against research and researchers. The vast majority simply never responded. Of all the firms I contacted, two expressed positive interest, which resulted in a few phone calls with mid- or upper-level people. Nevertheless, both eventually ended in radio silence; this is all very reminiscent of what Ortner (2010) went through in Hollywood.

One of these firms, however, had seemed fated to work out. A mid-level executive had been a journalist and was sympathetic to what I was seeking to do, and we 
exchanged a few phone calls. She asked me to send her an e-mail explaining my work, so I sent my most current explanation; these messages, as you will see, became subsequently much shorter and simpler:

\section{Columbia Anthropologist Introduction}

$6 / 27 / 13$

Dear Name Redacted,

I hope this note finds you well. Thank you again for taking the time to talk with me. As per your request, an explanation of my project follows.

I am an anthropologist at Columbia University, working on a dissertation on private equity investors. I study why and how people make investment and management decisions and the larger culture of private equity firms. I have been conducting life and work history interviews with people in private equity and other investment professions for the last year and am moving on to a more office-specific stage of my research.

I'm looking for a firm for the upcoming academic year at which I can watch the investment and management process unfold firsthand. [The firm] would be a particularly good research site because its focus on [a particular] sector gives it a coherent set of investment priorities and expertise. My hope is to start slowly, interviewing members of the firm, talking about life and work history. Then, if [the firm] is comfortable working with me, I would move into an on-site observational role. 
Should [the firm] be amenable to working with me, I would be more than happy to share my findings with the firm in whatever format is most usefulpresentations, reports, cultural assessments etc. In addition, it should be noted that my funding comes from Columbia or external granting agencies. ${ }^{4}$ As such I require no financial commitment of any kind from [the firm]. One further note- anthropologists have an obligation to those they study. As such I maintain the confidentiality of the people I work with.

Thank you again for your consideration. I am happy to explain my work further, and send along any appropriate supporting documentation from the university.

All the best,

Daniel

Daniel,

Thank you for your note and for your interest in [the firm]. Sounds like an interesting project, but we are going to pass.

Best of luck,

Name Redacted

Dear Name Redacted, 
Thanks very much for getting back to me. It's a bummer it won't work out. Should you have any advice for me, or know anyone who or any firm that might be keen to participate, please do let me know. Otherwise,

Take care and be well,

Daniel

That was that. This was the one and only exchange from my marathon of coldcalling, when I had the opportunity to try and explain myself, to a senior employee of a PE firm no less. It fizzled.

In an earlier version of this article, one reviewer (not from PoLAR) chastised me for taking such a misguided first attempt at contacting informants. The reviewer's contention was that the use of intermediaries, secretaries, websites, and e-mail addresses to reach people for study was foolish, and given that I ultimately found people in semipublic places, as one might for any other type of ethnographic study (more below), I should have done just that. More simply, I should not have recognized a difference between studying up and studying down; ethnography is ethnography, local norms be damned (the reviewer went on to note that had I taken their introductory methods class, I would have avoided all this heartache!).

Here is the rub: private equity investors, as one might expect powerful elites to do, structure their world in such a way that the only obvious, advertised way to reach them is through intermediated channels (those secretaries, websites, and e-mail accounts) that allow them to ignore most people who want to talk to them. Far more people want to 
contact them than they want to talk to. This sets up a conundrum: ethnographers, particularly in humanistic traditions, pride themselves on taking their informants seriously, on giving them the benefit of the doubt, and playing by the rules of the social scene they are observing. This is the right, warm, and fuzzy way to do fieldwork. Doing this when studying the powerful, though, it is easy to run into a dead end. ("We would love to talk to you! Please just place your comment in the complaint box. We take all feedback we get very seriously...”) While intermediation and gatekeeping can be hallmarks of any ethnographic site, it is fairly obvious the function it serves among financiers and private equity workers: the intentional sorting and diversion of people who do not belong to that social world. It is likely, too, that all elites maintain something like this to one degree or another, if only for logistical purposes.

Given this, to faithfully undertake anthropological research when studying up, a researcher has to reckon with the fact that gathering hundreds of pages of idly collected inscriptions of culture in a location of one's own choosing is highly unlikely. There may not even be a reliable site to watch — after all, in my case, does a private equity deal happen on an analyst's spread sheet? In a strategy session in Midtown Manhattan? On a site visit to Dubuque, Iowa? Through a sales agreement negotiated in a luxury hotel located anywhere? In the federal pension legislation that allows institutions to invest with private equity? The social processes by which private equity investors act encompasses these sites, and their power comes from orchestrating and arranging discrete sites and key moments into larger events. This is why a concrete strategy for finding key actors across all these locations is helpful. 


\section{Success}

Insofar as there was any breakthrough in my research, it was finding where private equity actors could be private equity actors in a semipublic place (again, as in Ortner 2010). In my first year of fieldwork, I had had a bit of success by posting bright green flyers and thereby soliciting informants in the halls of a local business school. I figured that the combination of a trusted space (the business school building, a semipublic place from which people go on to work in private equity) and giving people the opportunity to opt in (I left my contact information on the flyer) offered me more possible success than coldcalling ever did.

Given that place seemed to matter, a lecture Gillian Tett gave at the 2010 American Anthropological Association conference proved quite helpful. She noted that her reporters at the Financial Times needed to find a way to cover credits and derivatives markets. She likened the financial world to an iceberg with public markets like stocks and futures as above water. Beneath the water were lending, derivatives, insurance, and all the financial engineering that makes modern finance work. She also realized that her reporters were doing fairly conventional reporting, that is mostly rewriting bank press releases. Her dilemma: How could she get her reporters to observe finance workers who are surrounded by armies of PR workers and who do their business in private? She noted that people in finance regularly hold conferences, and suggested that her reporters go to them. 
What is more, in her talk she observed that such conferences hold a structurally similar position as Tajik marriage rituals that she studied for her graduate work. Both marriage rituals and finance conferences offer a back-door into studying the bigger issues in a social sphere: "They pull together a scattered group and through a series of formal and informal rituals that allow that group to restate its core social networks and restate its cognitive maps of how the world works," thereby "allowing the society to be reproduced through generations" (Tett 2010). Practically, both marriage rituals and finance conferences allow one to see a far-flung group of people in one place, often without a buffer of security or PR flaks.

Again, to me at least, as one who was straining to take my informants and their self-presentation seriously, I had no idea that such conferences existed, and that I might be able to attend them. Nothing I noticed in the literature prepared me for that sort of interstitial space; everything seemed geared toward the exchange, the market, the boardroom, the presentation; really, all the central mythical sites that financiers talk about when they talk about themselves. Keep in mind, too, that conferences are not mentioned on websites and do not come up in stories about private equity in books and papers, except, perhaps, as an oblique byline or reference to the site of a speech.

Shortly after the cold-calling debacle and listening to Tett's talk, I joined as many private equity-themed LinkedIn groups as I could, one of which sent the following conference advertisement:

Group: [Name of group] 
Subject: Hear ONLY From Private Equity Investors

Are you tired of hearing pitches from your competitors at every private equity event?

Wouldn't you rather hear from leading investors on what issues matter most to them, how they're allocating capital, and other critical issues to the success of your private equity firm?

On December 4th, we are hosting [redacted], a full-day conference where investors and ONLY investors will speak and share insights with the audience. [website address]

This is an affordable conference where you can hear directly from leading LPs and network with your private equity peers while enjoying catered meals at the [redacted] New York.

Every New York conference we have held recently has sold out so reserve your seat today: [website address]

[Signature]

P.S. [Redacted] is one of four conferences we are hosting in New York in December. Be sure to register for our Family Office Workshop, Capital Raising Workshop and Private Equity Networking Breakfast as well: [website address] 
By fall 2013 my interview schedule had slowed down dramatically. I had tapped out all the people my friends knew who worked in finance, and had exhausted their connections as well. Moreover, since I had not found a place to observe private equity business, I decided to go to this conference. The advertised price was around $\$ 400$ for one day, without breakfast. I called the organizers and pled poverty. They reduced the cost to around $\$ 200$. I reasoned this was much cheaper than, say, my colleague's ticket to India, so I took the plunge, paid up, and finally was able to conduct a bit of participant observation.

At the conference location, I collected a dozen business cards, and of those twelve, five people agreed to talk with me: one private equity worker, two limited partners (people who invest money with private equity), one family office worker (family offices are investment offices that invest the family fortunes of rich people), and one consultant to small businesses. One of the limited partners was able to refer me to two venture capital (VC) partners, who each referred me to another VC partner, as well as one PE partner. The one PE worker I met at the conference was not only an excellent informant but also told me about a university-networking event that she was organizing, which would be focused on private equity. From that event, I collected four more business cards, and conducted four interviews with those people (two private equity workers, one compliance worker, and one sales person of investment products to wealth managers). In total, this one LinkedIn advertisement led me to fourteen informants and two events (see Figure 1). 
[Please insert figure 1 about here.]

[Figure 1 caption: First Conference]

What should be immediately apparent from this informant chain is how varied informants' jobs are. I was still in the universe of private equity investors, but, as noted, at this conference I was able to find several PE investors, a family office manager, and a small-business consultant. These informants, in turn, led to more occupational diversity. Unlike a study of only investment bankers or a study rooted in a particular commodity exchange, by starting at a conference I picked up a broader cross-section of the world of finance than I might have with a more restricted sampling strategy, and in fact got to see how the process of a deal might hang together and who were the interested parties.

A description of such conferences is useful to give a sense of how these events unfold. Conferences are structured around a series of talks, a question-and-answer period; a meal or two; and scheduled, though unstructured, networking time. Everyone wears suits and is more or less eager to meet other people - conference networking is as welcoming as cold calling is not.

During the talks and Q and A time, I was able to take copious notes on a breadth of topics of concern to PE investors, often presented by mid- or senior-level people in private equity. The conferences had panels on all sorts of industry-specific themes that I had learned about peripherally in the financial press or from other informants: private equity and cleantech (technology that improves the efficiency of business processes by using renewable or cleaner forms of energy and industrial processes), venture capital 
portfolios, closed-pool funds and alternatives, private equity investing best practices, family office investing, and the world of limited partners.

At subsequent private equity conferences, I was able to hear themes and topics I was talking about in my interviews and which were being analyzed publicly. I also got to see how a room of finance professionals responded to and laughed at the stuff I was trying to learn about them (Souleles 2017a). I should also note that my age, race, and gender as well as my school affiliation helped me out. As a be-suited white male in my late 20s, and as a student at Columbia University, I could pass as a financier (or at least a wannabe), and was rarely called to account for myself (Sherwood 2010, 25). My informants would joke with me that I was doing this all to get a job in finance and never quite believed my demurral. No one came on to me; no one assaulted me; no one was suspicious of my presence. A few times when I explained I was an anthropologist, people were surprised, saying they took me either for a financier or someone looking for a job. My informants' expectations for my potential of working in their industry, and the industry's strong norms toward apprenticeship, all certainly helped with easier rapport after I found my way to conferences. I hasten to add, though, that I do not think my particular sociological profile is a necessary prerequisite to this type of study. ${ }^{5}$ Ethnography is more a matter of methods and art than of hard and fast rules. Someone who was not presumed to be seeking a job, presuming they could get in the door, would be able to play with other ambient social roles and identities and fit in in ways that are likely not obvious to me. Often, marked outsiders, though not greeted as warmly, are granted a bit more latitude or more easily fall into a confessional mode with their 
informants. It is possible that in many of my interviews people felt they were, at least initially, just offering me job advice, flexing the boundaries of elite sociality just enough to entertain a newcomer like me, and, as a consequence, were restrained. Moreover, informational job interviews often resemble open-ended conversations about a social space and one's attitudes toward it, looking like what ethnographers know of as an ethnographic interview (Spradley 1979). This is, perhaps, another reason why I had such success finding people to talk to at conferences.

As fruitful as conferences were for me, there was an added hurdle to studying up that is worth mentioning: scheduling (Ortner 2010). Even if one is able to make a friendly contact with an important person at a conference or networking event, or through other informants, one still has the daunting task of getting on someone's calendar. Everyone is busy; that is likely a truism of ethnographic work. What differs with private equity are both the nature of intermediation and systematic way people are held at a distance. Plenty of my colleagues have people fail to show up at appointments. Not many of my colleagues study people with full-time professional assistants who systematically limit access. In what follows, I reproduce excerpts of my attempts to schedule an interview with a venture capital partner whom I had met through four other informant links, which started with an internship at a business institute. The network at my internship included a university administrator looking to get into educational technology, a PE investor, an official at a relatively obscure federal agency involved with overseas financing, and, of course, a few venture capitalists - the investment "eco-system" is eclectic. I include lengthy excerpts not only because it is largely typical of my interaction with senior 
managers but also I feel there is a cumulative effect to seeing how exhausting this type of persistence is. Incidentally, this ended up being among my best interviews:

\section{$1 / 29 / 2014$}

Daniel-

Please meet [Assistant], who manages [Pluto's, a Partner in a Venture Capital Firm] calendar. [Assistant], please meet Daniel. If we could please find time on [Pluto's] calendar in the next couple of weeks for me, [Pluto] and Daniel to meet, that would be great.

Thanks!

[Gertrude, A media and PR specialist at Pluto's VC firm]

\section{$1 / 29 / 2014$}

Good to meet you [Assistant]. I hope you're well. Thanks very much for helping coordinate this.

Thursdays and Fridays tend to be my best days for scheduling. Tuesday and Wednesday before $[1 \mathrm{pm}]$ also work great. I hope this helps.

Take care, Daniel

\section{$1 / 31 / 2014$}

Nice to meet you, Daniel. 
Next week is completely booked. How about $2 / 11$ at $1 \mathrm{pm}$ ?

Regards,

[Assistant]

\section{$2 / 1 / 2014$}

Dear [Assistant],

Thanks again for helping with this.

$1 \mathrm{PM}$ on the 11th might be a bit tough. Let me give you my complete availability that week and if anything works we can go for it. Friday is completely open, Thursday is completely open, Wednesday is free except for 2:00 PM-4:30 PM, Tuesday is free except for 1:00 PM-4:30 PM, and Monday is a nightmare, but I am free before 9:00 AM and after 4:30 PM. If anytime in there works please do let me know. And Wednesday is negotiable, I can push things around if need be.

Take care,

Daniel

$2 / 3 / 2014$

Hi Daniel,

Would Friday at 4 pm work?

2/3/2014 
Dear [Assistant],

This Friday the 7th at 4 PM works great. Thanks very much for finding the time. This will be at [the firm's] office, right?

Take care,

Daniel

$2 / 3 / 2014$

Yes it will be at [the firm's office], Daniel. See you then!

$2 / 3 / 2014$

Hello again! As it turns out, [Gertrude] will be out on Friday so we have to reschedule.

Would you be available on Monday the 10th at $11 \mathrm{am}$ ?

$3 / 24 / 2014$

Thanks very much [Assistant]. Here are my next three weeks. With luck something works!

The week of April 1: 4/1 before 1 PM; 4/2 before 2 PM; 4/3 all day; 4/4 all day.

The week of April 7: 4/8 before 1 PM; 4/9 before 2 PM; 4/10 all day; 4/11 all day. 
The week of April 14: 4/15 before 1 PM; 4/16 before 2 PM; 4/17 all day; 4/18 after 2 PM.

Best,

Daniel

$3 / 28 / 2014$

Hi Daniel,

[Pluto] is going to be traveling and his calendar is over booked.

Can you give me 3 more weeks out after the below?

Kind regards,

\section{$3 / 28 / 2014$}

Sure thing!

The week of 4/21: Tues 4/22 before $1 \mathrm{PM}$; Weds 4/23 before $2 \mathrm{PM;} \mathrm{Thurs}$ 4/24 all day; Fri 4/25 all day.

The week of 4/28: Tues 4/29 before 1 PM; Weds $4 / 30$ before 2 PM; Thurs 5/1 all day; Fri 5/2 all day

The week of 5/5: Tues $5 / 6$ before 1 PM; Weds $5 / 7$ before 2 PM; Thurs $5 / 8$ all day.

Hope this helps!

Daniel 
[Time lapse]

\section{$5 / 14 / 2014$}

Oh Daniel!! I can not believe how busy [Pluto] has been. He is traveling all the time.

Would you please give me some more dates in June.

He is overbooked in May!

Thanks for your patience.

What ended up being successful for me was a combination of persistence, attending conferences "beginning with a small number of contacts ... [and] gradually expanding to a larger network" (Riles, 2011, 27), as Riles (2011) did in her study of legal reasoning in global financial markets. Also helpful was the general anthropological openness to any event at which I was invited or conversation with anyone who wanted to talk.

In studying hard-to-access people, Aguiar and Schneider (2012) note, "In other words, obstacles to access are challenging but should not provide an excuse to avoid committing to and persevering in studying up" (9). As irritating as this sentiment may be for someone having trouble gaining any sort of access to site or participants, I agree. I found no skeleton-key informant. Not surprisingly, no one offered me a job in private equity (although the Career Center at Columbia University coached me on résumé and cover-letter writing, and I applied for more than a few positions). I found private equity workers by going to their conferences and networking eents and ploddingly built informant networks. Ultimately, I think this led to a sample of informants that gave me a 
better sense of how PE investors fit into larger financial worlds than had I been embedded at one firm or found that golden informant.

\section{Finding a Site}

Increasingly, anthropological questions are drawing anthropologists away from the conventional sites of research. Particularly as one studies processes that span multiple groups of people in different geographic locations, there is value in thinking in terms of multiple sites and the processes that connect them (Marcus 1995), and imagining which of those multiple sites are open to research. This is a break from the larger norms of a discipline, which are captured in the constant use of the term "field site" and subsequent inquiries thereto ("What's your field site?"; "Where do you work again?"). Marcus helpfully notes that rather than any site of habitation, ethnographers - especially those who are interested in studying up or understanding social systems — often have networks or even social processes as their field sites.

Insofar as this is the case for studying up - treating power as a process and a verb, ethnographers will inevitably have trouble when they try to find sites where their informants live and work. My study of private equity investing is a good example of this. In my case, perhaps the most straightforward sites of private equity investing — offices and boardrooms - were simply closed to me (cf. Ortner 2010). I am sure there are circumstances under which I or other anthropologists might be able to negotiate access. Even as these places remain private to me, I found private equity people in a number of public fora and was able to build projects around these sites. Moreover, by finding 
interstitial informants who participate in the private equity deal process but are not themselves PE investors, I got a sense of how the larger social process of wealth allocation by investors worked. Methodological eclecticism has always been a strength of anthropological field work (Maalki 2007). Ill-considered fealty to an inappropriate method should not get in the way of ongoing research agendas; and I hope that ethnographers will always start with questions and allow the methods to come as appropriate.

Gusterson (1997) is on to something in his observation that one ought to consider varied sites of interaction, particularly for informants who go beyond single-sited, emplaced work. This is good advice, and not just when access is a problem. Ho (2009) is an interesting case in this regard. Ho both worked in the middle office of an investment bank, and then made use of work and alumni connections to build a network of investment banker informants to interview and hang out with. Ho went on to make generalizations about all of Wall Street and finance from this sample of data, even including PE investors in her formulation (4), and concluded that part of what makes finance do what it does is a sort of short-term, radically liquid ethos that runs across all of Wall Street (10-11). Spending a few moments with private equity investors illustrates that this explanation does not quite hold. Say what you will about the nature of private equity ownership and management of companies, ${ }^{6}$ private equity investors, in contrast to investment bankers, tend to have illiquid controlling ownership in the companies in which they invest, and are responsible for their management for up to ten years. Investment bankers, by contrast, generally only advise on the purchase or sale of a 
company. If sampling strategies led to a preponderance of investment bankers being interviewed, it is conceivable that the financial world could begin to look the way that they describe it.

By contrast, sampling strategies that open one up to the chaos and crossroads of conferences, meet-and-greets, networking sessions, and other face-to-face events would seem to prime a researcher for a heterogeneous, though related, sample group; and, one would hope, a better analysis of some social processes. Of course, the converse bias may apply in my own case. It is possible I learned of a larger social scene. However, there are also certainly things I simply will not be part of and will not be aware of because I did not spend time embedded in the minutiae of a specific private equity office. Put another way, I likely don't know what I don't know about the rhythms of an office or in knowing people's personal lives. This is because more conventional single-sited work was not available to me. If you add the position of the researcher, as I have commented on at various points in this manuscript, an apprehension of bias and the interplay of identity and access are even more nuanced. Still, having a clear research question and then letting methods follow, mitigates (but certainly does not remove) some of the pitfalls of this sort of bias. The eradication of bias in research is not necessarily a realistic goal; acknowledgement and mitigation of bias, though, is, particularly when it affects the types of elite networks one can even access.

My suggestions to the would-be studiers of elites and the powerful are two-fold. First, seek not the bounded group and their one special place. When interested in the powerful, one is generally interested in power understood as social processes that span 
geographic and social locations. A researcher is best served by understanding the mechanics of those social processes and the actors that bring them to life. To understand private equity, I needed an understanding of accountants, placement agents, investment bankers, company owners, company workers, and so on. Private equity may structure a lot of people's lives via the control they have over many large companies, but without all those different professionals that serve their industry there is no private equity. These processes come to life in shared, in-between social spaces. ${ }^{7}$

Second, while it may seem, particularly from the cognate literature on one's topic, that, in order to study up, a gatekeeping magical informant is essential to ethnographic success, this is not the case. Most simply, not everyone will find such an informant, and there are other ways to meet people., Even if $\backslash$ such an informant is not found, there is an added concern that, if one is not careful, one's subsequent research will be biased by the point of entry that particular person offers. To my mind, an excellent antidote to this is to sample widely in those shared, in-between social spaces.

\section{Notes}

${ }^{1}$ History, before its"cultural" and "people's" turn, had a bias in the other direction, that is, toward a record of famous, consequential people and their lives and times.

Consideration of elites actually has a longer disciplinary genealogy.

${ }^{2}$ The purchase of companies varies year to year. Wilmer Hale reported 28,829 companies were bought or sold in 2012. Extrapolating forward, this is can be used to estimate 2013 
company purchases and then the portion of private equity. WilmerHale, "M\&A Report," 2013, http://www.wilmerhale.com/uploadedFiles/WilmerHale_Shared_Content/Files/Editorial/ Publication/2013-wilmerhale-ma-report.pdf (site discontinued).

${ }^{3}$ It is worth noting that this reimagination of my methods came as a direct result of attending the National Science Foundation's Summer Institute in Research Design in Cultural Anthropology, with Professors Russ Bernard, Sue Weller, Jeff Johnson, and Amber Wutich. I thank all these people for the help they offered.

${ }^{4}$ This was optimistic to say the least. I only received, late in the second year of my work, a relatively small internal grant to support my research. To make ends meet, I taught and worked both as a teacher's assistant and research assistant throughout my fieldwork. I also received help from my family. External granting agencies, either thought the project was impossible or the research did not fit what they thought of as anthropological work, chose not support me.

${ }^{5}$ I must acknowledge that there are situations of social exclusion in which some identity categories are precluded from doing fieldwork. For example, early in my graduate training I worked at a Catholic monastery. A female researcher would not have been able to live in the cloister as I did. Similarly, I would not have been able to live in a convent. ${ }^{6}$ For an overview of such criticism, see Appelbaum and Batt 2014.

${ }^{7}$ Of course, there are plenty of research questions that will lead people to a fixed site and a fixed population. It is not that that sort of sample and research strategy is bad tout court, 
it is simply that when studying up, particularly in a big society, it can be a misguided default template. 


\section{References Cited}

Aguiar, Luis L. M., and Christopher J. Schneider, eds. 2012. Researching

Amongst Elites: Challenges and Opportunities in Studying Up. Burlington,

VT: Ashgate.

Appelbaum, Eileen, and Rosemary Batt. 2014. Private Equity at Work: When Wall Street Manages Main Street. New York: Sage.

Atkinson, Rowland, and John Flint. 2001. "Accessing Hidden and Hard-to-Reach Populations: Snowball Research Strategies." Social Research Update 33: insert page range.

Biernacki, Patrick, and Dan Waldorf. 1981. "Snowball Sampling: Problems and Techniques of Chain Referral Sampling." Sociological Methods \& Research 10 (2): 141-63.

Cohen, Jeffrey H. 2000. "Problems in the Field: Participant Observation and the Assumption of Neutrality." Field Methods 12 (4): 316-33.

Conti, Joseph A., and Moira O’Neil. 2007. “Studying Power: Qualitative Methods and the Global Elite." Qualitative Research 7 (1): 63-82.

Fisher, Melissa. 2012. Wall Street Women. Durham, NC: Duke University Press.

Flannery, Kent, and Joyce Marcus. 2012. The Creation of Inequality: How Our Prehistoric Ancestors Set the Stage for Monarchy, Slavery, and Empire. Cambridge, MA: Harvard University Press. 
Fogarty, Ignatius, ed. 2014. 2014 Preqin Global Private Equity Report. New York: Preqin Ltd.

Geertz, Clifford. 1973. The Interpretation of Cultures. New York: Basic Books. Gusterson, Hugh. 1996. Nuclear Rites: A Weapons Laboratory at the End of the Cold War. Berkeley: University of California Press.

— 1997. "Studying Up Revisited." PoLAR: Political and Legal Anthropology Review 20 (1): 114-19.

Harvey, William S. 2011. "Strategies for Conducting Elite Interviews." Qualitative. Research 11(4): 431-41.

Ho, Karen. 2009. Liquidated: An Ethnography of Wall Street. Durham, NC: Duke University Press.

—. 2015. "Supermanagers, Inequality, and Finance." Hau: Journal of Ethnographic Theory 5 (1): 481-88.

Holmes, Douglas. 2014. Economy of Words: Communicative Imperatives in Central Banks. Chicago: University of Chicago Press.

Kahn, Shamus. 2010. Privilege: The Making of an Adolescent Elite at St. Paul's School. Princeton, NJ: Princeton University Press.

Lévi-Strauss, Claude. 1968. Tristes Tropiques. Translated by John Russell. New York: Atheneum.

Levy, Jonathan. 2012. Freaks of Fortune: The Emerging World of Capitalism and Risk in America. Cambridge, MA: Harvard University Press. 
LiPuma, Edward, and Benjamin Lee. 2004. Financial Derivatives and the Globalization of Risk. Durham, NC: Duke University Press.

Malinowski, Bronislaw. (1922) 1966. Argonauts of the Western Pacific. Long Grove, IL: Waveland Press.

Maalki, Liisa H. 2007. "Tradition and Improvisation in Ethnographic Field Research.” In Improvising Theory: Process and Temporality in Ethnographic Fieldwork, 162-86. Chicago: University of Chicago Press. Marcus, George E. 1995. "Ethnography in/of the World System: The Emergence of Multi-Sited Ethnography.” Annual Review of Anthropology 24:95-117.

Mauer, Bill. 2006. Pious Property: Islamic Mortgages in the United States. New York: Russell Sage Foundation.

Merton, Robert K., and Elinor Barber. 2006. The Travels and Adventure of Serendipity: A Study in Sociological Semantics and the Sociology of Science. Princeton, NJ: Princeton University Press.

Mikecz, Robert. 2012. "Interviewing Elites: Addressing Methodological Issues." Qualitative Inquiry 18 (6): 482-93.

Miyazaki, Hirokazu. 2013. Arbitraging Japan: Dreams of Capitalism at the End of Finance. Berkeley: University of California Press.

Nader, Laura. 1972. "Up the Anthropologist: Perspectives Gained From Studying Up." Washington, DC: US Department of Health Education \& Welfare 
Office of Education. (ERIC Document Reproduction Service No.

ED065375). https://files.eric.ed.gov/fulltext/ED065375.pdf

Ortner, Sherry. 2010. “Access: Reflections on Studying Up in Hollywood."

Ethnography 11 (2): 211-33.

Ott, Julia. 2011. When Wall Street Met Main Street. Cambridge, MA: Harvard University Press.

Page, Benjamin, Larry M. Bartels, and Jason Seawright. 2013. "Democracy and the Policy Preferences of Wealthy Americans." Perspectives in Politics 11 (1): 51-73.

Riles, Annelise. 2011. Collateral Knowledge: Legal Reasoning in the Global Financial Markets. Chicago: University of Chicago Press.

Sherwood, Jessica Holden. 2010. Wealth, Whiteness and the Matrix of Privilege. New York: Lexington Books.

Souleles, Daniel.

2017a. “Don't Mix Paxil, Viagra, and Xanax: What Financiers Jokes Say about Inequality." Economic Anthropology 4 (1): 107-19.

_ 2017b. "Something New: Value and Change in Finance." Journal of Cultural Economy 10 (4): 393-404.

Forthcoming. Songs of Profit, Songs of Loss: Private equity, wealth, and inequality. Lincoln, Nebraska: University of Nebraska Press. 
Spradley, James P. 1979. The Ethnographic Interview. New York: Harcourt, Brace, Jovanovich.

Stephens, Neil. 2007. “Collecting Data from Elites and Ultra Elites: Telephone and Face-to-Face interviews with Macroeconomists." Qualitative Research 7 (2): 203-16.

Stiglitz, Joseph. 2011. "Of the 1\%, by the 1\%, for the 1\%." Vanity Fair, May. . 2013. The Price of Inequality: How Today's Divided Society Endangers Our Future. New York: Norton.

Tett, Gillian. 2010. "Silence and Silos: The Problems of Fractured Thought in Finance.” Inno-vent Session presented at the 109th Annual Meeting of the American Anthropological Association, New Orleans, LA. http://vimeo.com/17854712.

Weiss, Hadas. 2015. “Financialization and Its Discontents: Israelis Negotiating Pensions." American Anthropologist 117 (3): 506-18.

Winters, Jeffrey A. 2011. Oligarchy. Cambridge: Cambridge University Press.

Zaloom, Caitlin. 2006. Out of the Pits: Traders and Technology from Chicago to London. Chicago: University of Chicago Press. 